\title{
A Review of Various Scheduling Techniques Considering Energy Efficiency in WSN
}

\author{
Rajwinder Kaur \\ Post Graduate Student \\ Department of Computer Engineering and \\ Technology, Guru Nanak Dev University, \\ Amritsar, Punjab, India
}

\author{
Sandeep Sharma \\ Professor \\ Department of Computer Engineering and \\ Technology, Guru Nanak Dev University, \\ Amritsar, Punjab, India
}

\begin{abstract}
In advanced computing the Wireless Sensor Networks becomes the need of hour. The resources which are used in Wireless sensor Networks are limited in numbers. Resources are required to be allocated wisely to perform the numerous tasks in which job scheduling is always considered to be a key feature. Wireless sensor network has many sensor nodes as which are considered to be main components. Sensor node has limited energy and storage capabilities. So energy consumption in this field during scheduling is a biggest issue. This issue is carried out by many researchers and legion of algorithms are devised for achieving energy efficiency during scheduling of resources in wireless sensor networks. In this paper we have focused both the moving and stationery nodes for our study. Moving nodes are considered to be more prone to energy loss as compared to static nodes. This paper aims to study various techniques used to perform scheduling among such nodes to minimize energy consumption.
\end{abstract}

\section{Keywords}

Wireless Sensor Network, Job Scheduling, Fixed Nodes, Stationery Nodes, Energy Consumption

\section{INTRODUCTION}

Wireless sensor network is commonly used to monitor physical environment by deploying sensor nodes or for the purpose of monitoring other nodes also known as localization. WSN has vast applications but limited only in terms of energy consumption. Sensor nodes deployed within WSN has limited energy associated with it. Sensor nodes are deployed in order to collect information from area of concern. The collected information is passed to processing nodes. Hence sensor nodes collect the information, process it and communicate it further. There are four basic components associated with sensor nodes.

- $\quad$ Sensing unit

- Transceiver

- $\quad$ Processing unit

- $\quad$ Power unit

Sensing unit is used in order to collect the information in analog format. Analog to digital converters are employed to convert data fetched from analog to digital form. Microcontrollers are part of processing unit. The main task of transceiver is to transfer the data to other nodes. Transceiver joins the sensor nodes with the network. Power unit contains the battery required to operate all other modules of the node[1].

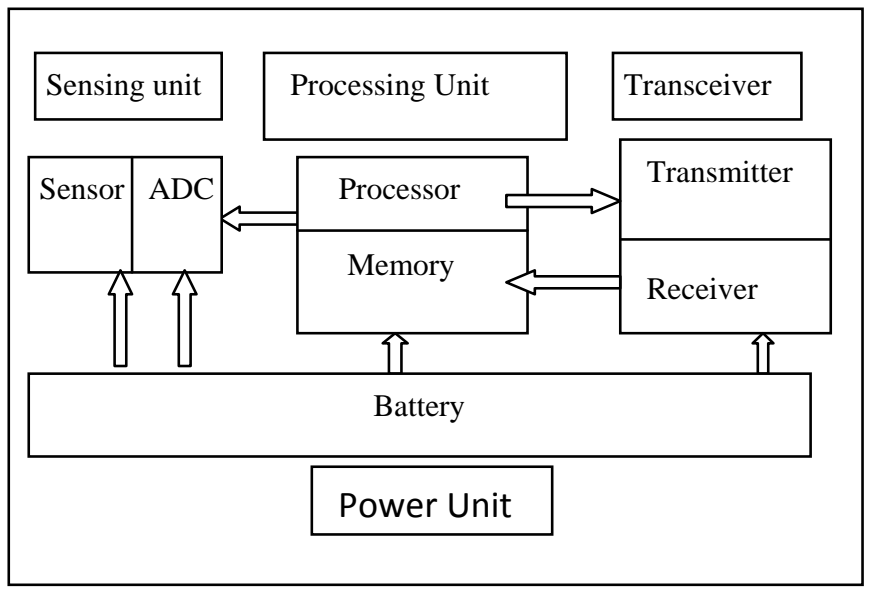

Fig 1: Components of sensor node [2]

The consumed energy in WSN has to be minimized for optimal performance of network. For accomplishing energy efficiency, algorithms related to scheduling are devised by researchers.

This paper deals with various algorithms working towards energy efficiency during scheduling in WSN. Rest of the paper is organised as under: Section II describes the general consideration in WSN, Section III describes scheduling schemes used in WSN, Section IV describes comparison of scheduling algorithms in various papers where as last section describes conclusions.

\section{GENERAL CONSIDERATIONS IN WSN}

Wireless sensor nodes are deployed in many areas such as environmental monitoring, land monitoring, air pollution monitoring etc. The critical factors which must be considered while using WSN in the above listed fields are described as under

- There is a power consumption constraint for nodes [3].

- Fault tolerance mechanism deployment in case of node failure[4].

- Nodes can move around within the network. So mobility is critical factor in determining energy consumption[5].

- Nodes are of different kinds or heterogeneous in nature[6].

- WSN design should able to withstand harsh environmental conditions[7]. 
All the above listed considerations are critical in success of the WSN in terms of operations which it required to perform.

\section{SCHEDULING SCHEMES}

Legion of research is carried out to devise algorithms which can be used in order to provide energy efficient scheduling in WSN. Sensor nodes have limited energy associated with it. Hence energy consumption has to be minimized. This section provides description of such algorithms.

Scheduling in multi-cluster environment is critical area of research. Legion of scheduling algorithms are playing a part to schedule resources in multi cluster environment. Task can arrive from geographically large area and this present a challenge that which task must be given a resource at first place. In multi cluster environment Computer, data, and other resources are shared[8]. The service provider and consumers must agree upon what to be shared within given environment. The global nature of resource sharing is unique facility provided within multi cluster environment. The resource may be present within different administrative domain and demanded by node belonging to some other domain[9]. Scheduling henceforth becomes important for optimal and deadlock free system.

Sleep scheduling algorithm is efficient mechanism to manage energy in wireless sensor network. In this approach nodes within the network are allowed to sleep using sleep algorithm while some of the nodes are active. It means all the nodes are not active all the times hence energy consumption is reduced considerably[10].

Scheduling is the process of assigning resources to jobs based on objective functions defined. Type of scheduling depends upon the objective function associated with the resource. Scheduling resources has following phases associated with it

- Resource Discovery

- $\quad$ Resource Filtering

- $\quad$ Resource Selection

- $\quad$ Resource Scheduling Policy

Before allocation within multi cluster environment, resources must be discovered. Resource may or may not be available[8]. Hence this phase becomes critical for monitoring of resource within the system[11]. The available resources must be checked to determine whether they satisfy the requirements or not. Hence filtering is compulsory. Resource selection out of available resources is next phase. This phase is critical since out of available resources of same type resource with optimal condition is selected for allocation. This is required so that job can be completed well within time. Healthier resource selection is the target of this phase. Scheduling policy decides the resource allocation is primitive or not. Resource allocation is said to be primitive if once allocation resource can be prompted from task even if it is not yet fully completed.

In this job scheduling algorithm job is distributed to the processor within the system on the first come first serve basis. This algorithm may or may not yield optimal solutions. [12]The allocated processor release the job when the job burst time finishes. This algorithm is strictly non primitive in nature. It is hence rarely utilized in the parallel environment.

In this scheduling time is shared among multiple jobs. The time sharing system utilizes time quantum. The processor is switched among the processors based on time quantum. The process continues until all the jobs finish execution. The time sharing system involves states such as waiting, active and ready. The time scheduling on parallel system can be implemented using local scheduling. The processing node has processors associated with them. Threads ready to be executed are placed within first come first serve buffer.[13] When the processor is available thread is fetched from the queue and executed. The rime sharing environment generally adopt pipeline concept for executing instructions concurrently within uniprocessor systems.

This algorithm is considered one of the best algorithms in order to schedule the resources and allocate jobs to the processors. The characteristics of ants are followed in this case. The ants communicate with each other and let the information spread to detect optimal path. The base of parallel ant colony is implemented using parallel construction phase. In parallel ant colony algorithm multiple colonies are built simultaneously. The output of all the colonies is compared with each other. The output generated by colonies is checked for optimality. [13]

The only problem with the ACO is the convergence of ant colony algorithm is slow. The distance covered using this algorithm is short. In order to resolve the problem honey bee algorithm can be utilized.

This algorithm utilizes better features of Ant Colonies algorithm along with high distance capabilities. The Honey bee algorithm utilizes optimal path finding along with distance coverage. It utilizes the foraging system associated with honey bees to find the path out of available alternatives. This algorithm converges much faster as compared to existing ant colony algorithm.[14]

The genetic algorithm has phases associated with it. The algorithm continues until optimal result is obtained. The phases associated with genetic algorithms are initialization, mutation crossover etc. The genetic algorithm goes through the generations and in case of complex problems consumes large amount of time. so for smaller problems genetic algorithm is not preferred. The genetic algorithm terminates when solution reaches satisfactory level. The prescribed tolerance hence plays critical part in terminating genetic algorithm. [15]-[17]

The approach using ant colony and honey bee algorithm can be used in order to enhance job scheduling performance. The ant colony algorithm utilizes to select path which is optimal in nature. The ant colony algorithm however is distance dependent. In order to resolve the problem honey bee algorithm is utilized. Honey bee may not always give optimal path but speed is enhanced considerable. The honey bee algorithm is not distance dependent. Parallel ant colony algorithm is need of the hour in which multiple process can be executed at the same time [13], [14], [18].

Another scheduling mechanism is node scheduling mechanism. Node has to examine off duty rules in this approach. This is done during self scheduling stage. In this approach node examine whether the its sensing region lie within the sensing region of its neighbour or not. If sensing region lies in the sensing region of its neighbour then it turn off its sensing. Hence energy is conserved[19].

In centralized and node disjoint heuristic sensing radius is analysed. The nodes have certain radius associated with it. Node examine radius and if region lies within the range then node perform sensing operation. The smallest distance approach is also utilized in this case. The distance of neighbour sensing node is considered in this case. The sensor nodes if are closer than they are allowed to sense the network. Energy is conserved since longest or far sensor nodes are 
switched off and closer nodes are allowed to sense the network[20].

TDMA scheduling algorithm uses time slots and allocate it to particular sensor node. The sensor node transfers the data on the basis of slots. The sensor nodes wait for its turn to arrive. As sensor node turn arrives it broadcast its operation. During the idle period sensor node can be switched off. Hence energy conservation mechanism is present[21].

The hybrid approach by combining optimal features of various scheduling approach can enhance energy efficiency. Next section presents comparison of various scheduling algorithms.

General consideration in scheduling algorithms is described through following comparison table

Table 1: General attribute comparison of scheduling approach

\begin{tabular}{|l|l|l|l|}
\hline Technique & $\begin{array}{l}\text { Parameters of } \\
\text { Scheduling }\end{array}$ & $\begin{array}{l}\text { Facts } \\
\text { discovered }\end{array}$ & Methodology \\
\hline $\begin{array}{l}\text { First Come } \\
\text { First Serve[9] }\end{array}$ & $\begin{array}{l}\text { Time Of } \\
\text { Submission, } \\
\text { Processing } \\
\text { Time, Finish } \\
\text { Time }\end{array}$ & $\begin{array}{l}\text { Utilization } \\
\text { of resources } \\
\text { is low }\end{array}$ & $\begin{array}{l}\text { MATLAB, } \\
\text { NS2,C SP2 }\end{array}$ \\
\hline $\begin{array}{l}\text { Backfilling } \\
\text { Algorithm[22] }\end{array}$ & Job Burst Time & $\begin{array}{l}\text { Shortest job } \\
\text { move ahead } \\
\text { of other } \\
\text { jobs }\end{array}$ & $\begin{array}{l}\text { Simulation is } \\
\text { event based }\end{array}$ \\
\hline $\begin{array}{l}\text { Conservative } \\
\text { Backfilling } \\
\text { Algorithm[23] }\end{array}$ & $\begin{array}{l}\text { Arrival Time, } \\
\text { Processing } \\
\text { Time, Finish } \\
\text { Time }\end{array}$ & $\begin{array}{l}\text { Resource } \\
\text { utilization } \\
\text { is improved }\end{array}$ & Simulation is \\
event based
\end{tabular}

\begin{tabular}{|l|l|l|l|}
\hline Scheduling[33] & $\begin{array}{l}\text { Number Of } \\
\text { Jobs }\end{array}$ & $\begin{array}{l}\text { utilization } \\
\text { of resources }\end{array}$ & $\begin{array}{l}\text { cluster based } \\
\text { environment }\end{array}$ \\
\hline $\begin{array}{l}\text { Buddy } \\
\text { Allocation } \\
\text { Mechanism[32] }\end{array}$ & $\begin{array}{l}\text { Jobs Are } \\
\text { Partitioned }\end{array}$ & $\begin{array}{l}\text { Improve } \\
\text { utilization } \\
\text { of resources }\end{array}$ & CLOUDSIM \\
\hline
\end{tabular}

\section{LITERATURE SURVEY}

(Zhou et.al 2015) [34] Proposed the technique of dividing the network into grids cells which are of equal size and shape. Using algorithm that is based on k-dimensional tree algorithm grid cells are assigned to clusters such that while collecting data the energy consumed by each cluster is same. Further data is collected from the cluster heads by a mobile sink which is routed through the network using Travelling salesman problem. The clusters are adjusted by allocating or deal locating the grid cells contained in a cluster for balancing energy consumed by the for sink movement. By balancing energy consumed in data gathering and sink mobility it prolongs the network lifetime.

(Chatterjie et.al 2014) [35] In multiple hop single sink system node close to the sink dissipate energy at faster rate as it transfer all the packets from network to sink due to which energy holes are formed near sink. To improve network lifetime this paper proposed a network with multiple sinks in order to balance the load. Network is divided into clusters. Cluster diameter and number of clusters are optimized to reduce deployment of sink nodes.

(Chu-Fu Wang et.al 2014)[36] Proposed a network lifetime enhancement method by sink relocation according to the residual energy of sensor node. Energy-Aware Sink Relocation (EASR) is a method in which the main focus on residual energy of sensor node and according to that transmission range of sensor is adjusted and the relocation of sink is done.

(Zijan Wang et.al 2009) [37] Proposed an energy efficient and collision aware (EECA) node-disjoint multipath routing algorithm for wireless sensor networks. With node position information this algorithm try to find two collision-free routes using constrained and power adjusted flooding and then data is transmitted with minimum power required as per power control component.

(Maciej Nikodem et.al 2011)[38] concentrated on if clustering all alone (without data aggregation) can improve lifetime of wireless sensor network in comparison with non-clustering network. As per capabilities of real-life nodes, using integer linear programming they examine $1 \mathrm{D}$ and $2 \mathrm{D}$ networks. Results roll out that additional techniques are required as clustering alone can't improve network lifetime.

This section provides comparison of various algorithms used to enhance energy efficiency. This comparison can be used for selection of optimal algorithm for future research.

Table 2: Comparison of techniques for energy efficient algorithms in WSN

\begin{tabular}{|l|l|l|l|}
\hline Authors & Reference & $\begin{array}{l}\text { Technique } \\
\text { Used }\end{array}$ & Findings \\
\hline $\begin{array}{l}\text { Zhou et } \\
\text { al. }\end{array}$ & $\begin{array}{l}\text { [34]Energy } \\
\text { Balanced } \\
\text { Heuristic for } \\
\text { energy }\end{array}$ & $\begin{array}{l}\text { Three phase } \\
\text { approach to } \\
\text { achieve energy }\end{array}$ & $\begin{array}{l}\text { Lifetime of } \\
\text { network is } \\
\text { enhanced }\end{array}$ \\
\hline
\end{tabular}




\begin{tabular}{|c|c|c|c|}
\hline & efficiency & efficiency & \\
\hline $\begin{array}{l}\text { Chatterje } \\
\text { e et al. }\end{array}$ & $\begin{array}{l}\text { [35]Multiple } \\
\text { Sink } \\
\text { Deployment in } \\
\text { WSN }\end{array}$ & $\begin{array}{l}\text { A multi sink } \\
\text { deployment } \\
\text { technique is } \\
\text { used to enhance } \\
\text { energy } \\
\text { efficiency }\end{array}$ & $\begin{array}{l}\text { Delay time is } \\
\text { reduced }\end{array}$ \\
\hline $\begin{array}{l}\text { Resstucia } \\
\text { et al. }\end{array}$ & $\begin{array}{l}\text { [39]Lifetime } \\
\text { optimization } \\
\text { with QoS }\end{array}$ & $\begin{array}{l}\text { Swarm based } \\
\text { optimization is } \\
\text { used }\end{array}$ & $\begin{array}{l}\text { Quality of } \\
\text { service } \\
\text { ensured } \\
\text { energy } \\
\text { efficiency }\end{array}$ \\
\hline $\begin{array}{l}\text { Omer et } \\
\text { al }\end{array}$ & $\begin{array}{l}\text { [40]Optimal } \\
\text { base station } \\
\text { mobility }\end{array}$ & $\begin{array}{l}\text { Mixed integer } \\
\text { programming } \\
\text { framework is } \\
\text { utilized }\end{array}$ & $\begin{array}{l}\text { Higher } \\
\text { network } \\
\text { lifetime } \\
\text { ensured }\end{array}$ \\
\hline Jose et al. & $\begin{array}{l}\text { [2]Energy } \\
\text { efficient routing } \\
\text { scheme using } \\
\text { sink nodes }\end{array}$ & $\begin{array}{l}\text { MSA algorithm } \\
\text { is utilized }\end{array}$ & $\begin{array}{l}\text { Better } \\
\text { performance is } \\
\text { observed }\end{array}$ \\
\hline $\begin{array}{l}\text { Chu-fang } \\
\text { et al }\end{array}$ & $\begin{array}{l}\text { [36]A network } \\
\text { lifetime } \\
\text { enhancement }\end{array}$ & $\begin{array}{l}\text { Energy aware } \\
\text { sink relocation }\end{array}$ & $\begin{array}{ll}\text { Lifetime } & \text { of } \\
\text { network } & \text { is } \\
\text { increased. } & \end{array}$ \\
\hline $\begin{array}{l}\text { Devasvar } \\
\text { an et al }\end{array}$ & $\begin{array}{l}\text { [41]Energy } \\
\text { efficient } \\
\text { protocol in } \\
\text { WSN }\end{array}$ & $\begin{array}{l}\text { Energy efficient } \\
\text { protocol with the } \\
\text { use of mobile } \\
\text { base station is } \\
\text { used }\end{array}$ & $\begin{array}{ll}\text { Life time of } \\
\text { network } & \text { is } \\
\text { enhanced } & \end{array}$ \\
\hline Far et al & $\begin{array}{l}{[42] \text { Wireless }} \\
\text { sensor network } \\
\text { energy } \\
\text { minimization } \\
\text { using mobile } \\
\text { sink nodes }\end{array}$ & $\begin{array}{l}\text { Fuzzy Logic } \\
\text { technique is } \\
\text { utilized }\end{array}$ & $\begin{array}{l}\text { Better energy } \\
\text { conservation } \\
\text { mechanism is } \\
\text { proposed }\end{array}$ \\
\hline $\begin{array}{l}\text { X.Zhang } \\
\text { et al }\end{array}$ & $\begin{array}{l}\text { [43]A data } \\
\text { gathering } \\
\text { scheme using } \\
\text { partitioning } \\
\text { algorithm }\end{array}$ & $\begin{array}{l}\text { Data gathering } \\
\text { scheme is } \\
\text { utilized through } \\
\text { zone } \\
\text { partitioning }\end{array}$ & $\begin{array}{l}\text { Better latency is } \\
\text { observed in } \\
\text { terms of energy } \\
\text { efficiency }\end{array}$ \\
\hline Farzad et al & $\begin{array}{l}{[44] \text { On }} \\
\text { maximizing } \\
\text { the lifetime of } \\
\text { WSN }\end{array}$ & $\begin{array}{l}\text { Convex } \\
\text { optimization } \\
\text { Technique }\end{array}$ & $\begin{array}{ll}\text { Lifetime } & \text { of } \\
\text { network } & \text { is } \\
\text { enhanced } & \end{array}$ \\
\hline Wang et al & $\begin{array}{l}\text { [45]Performan } \\
\text { ce analysis of } \\
\text { WSN }\end{array}$ & $\begin{array}{l}\text { Mobility } \\
\text { assisted data } \\
\text { collection }\end{array}$ & $\begin{array}{l}\text { Performance } \\
\text { of WSN is } \\
\text { improved }\end{array}$ \\
\hline Shuai et al & $\begin{array}{l}{[46] \text { Efficient }} \\
\text { data collection } \\
\text { in WSN }\end{array}$ & $\begin{array}{l}\text { Maximum } \\
\text { amount shortest } \\
\text { path }\end{array}$ & \begin{tabular}{|l} 
Energy \\
conservation \\
is achieved
\end{tabular} \\
\hline Wang et al & $\begin{array}{l}\text { [47]Extending } \\
\text { the lifetime of } \\
\text { WSN }\end{array}$ & $\begin{array}{l}\text { Mobile relays } \\
\text { are used }\end{array}$ & $\begin{array}{l}\text { Life time of } \\
\text { network is } \\
\text { comprehensively } \\
\text { enhanced }\end{array}$ \\
\hline
\end{tabular}

\begin{tabular}{|c|c|c|c|}
\hline Rao et al & $\begin{array}{l}{[48] \text { Energy }} \\
\text { efficient } \\
\text { schemes for } \\
\text { wireless } \\
\text { sensor } \\
\text { network with } \\
\text { multiple base } \\
\text { station }\end{array}$ & $\begin{array}{l}\text { Integer } \\
\text { programming }\end{array}$ & $\begin{array}{l}\text { By the } \\
\text { application of } \\
\text { this model } \\
\text { lifetime of } \\
\text { network is } \\
\text { enhanced }\end{array}$ \\
\hline Wang et al & $\begin{array}{l}\text { [49]Exploiting } \\
\text { sink mobility } \\
\text { for maximizing } \\
\text { sensor node } \\
\text { lifetime }\end{array}$ & $\begin{array}{l}\text { Linear } \\
\text { optimization } \\
\text { Model }\end{array}$ & $\begin{array}{ll}\text { Lifetime } & \text { of } \\
\text { network } & \text { is } \\
\text { improved } & \end{array}$ \\
\hline
\end{tabular}

From the above comparison table it is clear to predict the optimal algorithm. Most of the existing techniques enhance the lifetime of the network. Hybridization can be used in the future to enhance energy conservation in WSN.

\section{CONCLUSION AND FUTURE WORK}

In this paper we have studied the existing methods and their implementations for energy enhancement. Present work largely emphasised on the lifetime enhancement by energy conservation. Static and mobile modes are causes of energy dissipation in wireless sensor network. Mobile nodes generally consume higher energy as compared to static nodes. The parameters considered in existing literature for validation of the work involves end to end delay, throughput and packet delivery ratio. The study indicates that dynamic sink nodes are better in terms of end to end delay which can be minimized at the cost of increase of packet drop ratio. Various scheduling algorithms for mobile and stationary nodes are presented through comparative analysis.

In future, hybrid scheduling may be proposed by combining sink node scheduling with mobile nodes. A good mix of mobile and static nodes for specified purposes can be used so that lifetime can be enhanced in which the mobile nodes can be made rechargeable and motion of mobile nodes can be optimized to save their energy.

\section{REFERENCES}

[1] A. Kaur and A. Singh, "A Review on Enhancement of Lifetime of Wireless Sensor Network using Prediction Based Mobile Sink Path Determination : a Review," pp. 14120-14126, 2016.

[2] D. V Jose and G. Sadashivappa, "a Novel Energy Efficient Routing a Lgorithm for Wireless Sensor Networks," Int. J. Wirel. Mob. Networks, vol. 6, no. 6 , pp. 15-25, 2014.

[3] R. Ramya, G. Saravanakumar, and S. Ravi, "Energy Harvesting in Wireless Sensor Networks," Springer India, 2016, pp. 841-853.

[4] M. Azharuddin and P. K. Jana, "A distributed algorithm for energy efficient and fault tolerant routing in wireless sensor networks," Wirel. Networks, vol. 21, no. 1, pp. 251-267, 2015.

[5] A. Mateska, L. Gavrilovska, and S. Nikoletseas, "Mobility Aspects in WSN," Springer London, 2011, pp. 119-143.

[6] S. Chand, S. Singh, and B. Kumar, "Heterogeneous HEED protocol for wireless sensor networks," Wirel. Pers. Commun., vol. 77, no. 3, pp. 2117-2139, 2014. 
[7] F. M. Al-Turjman, H. Hassanein, S. Oteafy, and W. Alsalih, "Towards augmenting federated wireless sensor networks in forestry applications," Pers. Ubiquitous Comput., vol. 17, no. 5, pp. 1025-1034, 2013.

[8] T. Kokilavani and D. I. G. Amalarethinam, "Reduced Makespan Task Scheduling Algorithm for Grid Computing," vol. 9, no. 27, pp. 71-76, 2016.

[9] V. Hamscher, U. Schwiegelshohn, A. Streit, R. Yahyapour, R. Buyya, and M. Baker, "Evaluation of JobScheduling Strategies for Grid Computing," Grid Comput., vol. 1971, pp. 191-202, 2000.

[10] S. D. Dwivedi and P. Kaushik, "Energy Efficient Routing Algorithm with sleep scheduling in Wireless Sensor Network," vol. 3, no. 3, pp. 4350-4353, 2012.

[11] C. Wu, J. Li, D. Xu, P.-C. Yew, J. Li, and Z. Wang, "FPS: A Fair-Progress Process Scheduling Policy on Shared-Memory Multiprocessors," IEEE Trans. Parallel Distrib. Syst., vol. 26, no. 2, pp. 444-454, Feb. 2015

[12] I. J. I. Systems, M. S. Garshasbi, M. Effatparvar, and A. Branch, "High Performance Scheduling in Parallel Heterogeneous Multiprocessor Systems Using Evolutionary Algorithms," no. October, pp. 89-95, 2013.

[13] P. Delisle and P. Delisle, "Parallel Ant Colony Optimization: Algorithmic Parallel Ant Optimization: Algorithmic Models Models and Colony Hardware Implementations and Hardware Implementations."

[14] B. Yuce, M. S. Packianather, E. Mastrocinque, D. T. Pham, A. Lambiase, and T. Parade, "Honey Bees Inspired Optimization Method: The Bees Algorithm," pp. 646-662, 2013.

[15] E. Gabaldon, J. L. Lerida, F. Guirado, and J. Planes, "Multi-criteria genetic algorithm applied to scheduling in multi-cluster environments," J. Simul., vol. 9, no. 4, pp. 287-295, 2015

[16] W. Abdulal, A. Jabas, S. Ramachandram, and O. Al Jadaan, "Task Scheduling in Grid Environment Using Simulated Annealing and Genetic Algorithm," 2012.

[17] S. G. Ahmad, C. S. Liew, E. U. Munir, T. F. Ang, and S. U. Khan, "A hybrid genetic algorithm for optimization of scheduling workflow applications in heterogeneous computing systems," J. Parallel Distrib. Comput., vol. 87 , pp. 80-90, 2016

[18] R. Singh, "Task Scheduling in Parallel Systems using Genetic Algorithm," vol. 108, no. 16, pp. 34-40, 2014

[19] S. Gupta and K. C. Roy, "Comparison of Sensor Node Scheduling Algorithms in Wireless Sensor Networks," Int. Res. J. Eng. Technol., vol. 2, no. 6, pp. 97-104, 2015.

[20] L. Aslanyan, H. Aslanyan, and H. Khosravi, "Optimal node scheduling for integrated connected-coverage in wireless sensor networks," CSIT 2013 - 9th Int. Conf. Comput. Sci. Inf. Technol. Revis. Sel. Pap., 2013.

[21] S. C. Ergen and P. Varaiya, "TDMA scheduling algorithms for wireless sensor networks," Wirel. Networks, vol. 16, no. 4, pp. 985-997, 2010.

[22] F. Xhafa and A. Abraham, "Meta-heuristics for grid scheduling problems," ... Sched. Distrib. Comput. ..., pp. $1-37,2008$
[23] A. Mishra, S. Mishra, and D. S. Kushwaha, "An Improved Backfilling Algorithm: SJF-BF," vol. 05, no. 01, 2011.

[24] F. A. B. Silva, E. P. Lopes, E. P. L. Aude, F. Mendes, T. C. Júlio, H. Serdeira, M. Martins, and W. Cirne, "Response Time Analysis of Gang Scheduling for Real Time Systems."

[25] L. R. Dror G. Feitelson, D. G. Feitelson, and L. Rudolph, "Parallel Job Scheduling: Issues and Approaches," Jsspp, vol. 949, pp. 1-18, 1995.

[26] K. Deb, A. Pratap, S. Agarwal, and T. Meyarivan, "A fast and elitist multiobjective genetic algorithm: NSGAII," IEEE Trans. Evol. Comput., vol. 6, no. 2, pp. 182197, Apr. 2002.

[27] R. Nedunchezhian and P.Vivekanandan, "a Fast Genetic Algorithm for Mining Classification Rules in," Soft Comput., vol. 1, no. 1, pp. 10-20, 2010.

[28] J. Carretero, F. Xhafa, and A. Abraham, "Genetic Algorithm Based Schedulers for Grid Computing Systems," Int. J. Innov. Comput. Inf. Control, vol. 3, no. 6, pp. 1-19, 2007.

[29] D. Maruthanayagam and R. UmaRani, "Enhanced Ant Colony Algorithm for Grid Scheduling," Int. J. Comput. Technol. Appl., vol. 1, no. 1, pp. 43-53, 2010.

[30] M. Wang and W. Zeng, "A comparison of four popular heuristics for task scheduling problem in computational grid," 2010 6th Int. Conf. Wirel. Commun. Netw. Mob. Comput. WiCOM 2010, pp. 3-6, 2010.

[31] S. Sharma, A. Chhabra, and S. Sharma, "Comparative Analysis of Scheduling Algorithms for Grid Computing," pp. 349-354, 2015.

[32] A. Kousalya and R. Radhakrishnan, "A Comparative Study of Parallel Job Scheduling Algorithms in Cloud Computing," vol. 6, no. 3, pp. 2687-2690, 2015.

[33] H. D. Karatza, "SCHEDULING GANGS IN A DISTRIBUTED SYSTEM," vol. 7, no. 1, pp. 15-22, 2000.

[34] Z. Zhou, C. Du, L. Shu, G. Hancke, J. Niu, and H. Ning, "An Energy-Balanced Heuristic for Mobile Sink Scheduling in Hybrid WSNs," IEEE Trans. Ind. Informatics, vol. 12, no. 1, pp. 28-40, 2016.

[35] P. Chatterjee and N. Das, "Multiple sink deployment in multi-hop wireless sensor networks to enhance lifetime," Proc. - Int. Conf. 2015 Appl. Innov. Mob. Comput. AIMoC 2015, pp. 48-54, 2015.

[36] C.-F. Wang, J.-D. Shih, B.-H. Pan, and T.-Y. Wu, "A Network Lifetime Enhancement Method for Sink Relocation and Its Analysis in Wireless Sensor Networks," IEEE Sens. J., vol. 14, no. 6, pp. 1932-1943, Jun. 2014.

[37] Zijan Wang, and Eyuphan Bulut, "Energy Efficient Collision Aware Multipath Routing for Wireless Sensor Networks", International Conference on Communications, IEEE, (2009), 1-5.

[38] Maciej Nikodem and Bartosz Wojciechowski, "Upper Bounds on Network Lifetime for Clustered Wireless Sensor Networks", $4^{\text {th }}$ IFPI International Conference, IEEE, (2011), 1-6. 
[39] F. Restuccia and S. K. Das, "Lifetime optimization with QoS of sensor networks with uncontrollable mobile sinks," in 2015 IEEE 16th International Symposium on A World of Wireless, Mobile and Multimedia Networks (WoWMoM), 2015, pp. 1-9.

[40] O. Cayirpunar, E. Kadioglu-Urtis, and B. Tavli, "Optimal Base Station Mobility Patterns for Wireless Sensor Network Lifetime Maximization," IEEE Sens. J., vol. 15, no. 11, pp. 6592-6603, Nov. 2015.

[41] V. Devasvaran, N. M. A. Latiff, and N. N. N. A. Malik, "Energy efficient protocol in wireless sensor networks using mobile base station," in 2014 IEEE 2nd International Symposium on Telecommunication Technologies (ISTT), 2014, pp. 56-60.

[42] B. E. Far, S. Alirezaee, and S. V. Makki, "Wireless sensor network energy minimization using the mobile sink," in 7'th International Symposium on Telecommunications (IST'2014), 2014, pp. 1184-1188.

[43] X. Zhang, H. Bao, J. Ye, K. Yan, and H. Zhang, "A Data Gathering Scheme for WSN/WSAN Based on Partitioning Algorithm and Mobile Sinks," in 2013 IEEE 10th International Conference on High Performance Computing and Communications \& 2013 IEEE International Conference on Embedded and Ubiquitous Computing, 2013, pp. 1968-1973.

[44] F. Tashtarian, M. H. Yaghmaee Moghaddam, K. Sohraby, and S. Effati, "On Maximizing the Lifetime of
Wireless Sensor Networks in Event-Driven Applications With Mobile Sinks," IEEE Trans. Veh. Technol., vol. 64, no. 7, pp. 3177-3189, 2015.

[45] W. Liu, K. Lu, J. Wang, G. Xing, and L. Huang, "Performance Analysis of Wireless Sensor Networks With Mobile Sinks," IEEE Trans. Veh. Technol., vol. 61, no. 6, pp. 2777-2788, Jul. 2012.

[46] S. Gao, H. Zhang, and S. K. Das, "Efficient Data Collection in Wireless Sensor Networks with PathConstrained Mobile Sinks," IEEE Trans. Mob. Comput., vol. 10, no. 4, pp. 592-608, Apr. 2011.

[47] Wei Wang, V. Srinivasan, and Kee-Chaing Chua, "Extending the Lifetime of Wireless Sensor Networks Through Mobile Relays," IEEE/ACM Trans. Netw., vol. 16, no. 5, pp. 1108-1120, Oct. 2008.

[48] Gandham, S.r., M. Dawande, R. Prakash, and S. Venkatesan, "Energy efficient schemes for wireless sensor networks with multiple mobile base stations."GLOBECOM '03. IEEE Global Telecommunications Conference (IEEE Cat. No.03CH37489). doi:10.1109/glocom.2003.1258265.

[49] Z. M. Wang, S. Basagni, E. Melachrinoudis, and C. Petrioli, "Exploiting Sink Mobility for Maximizing Sensor Networks Lifetime," in Proceedings of the 38th Annual Hawaii International Conference on System Sciences, p. 287a-287a 